\title{
Hubungan Karakteristik Dan Tingkat Kesejahteraan Petani Pada Usahatani Karet (Studi Kasus Di Desa Teraju Kecamatan Toba Kabupaten Sanggau)
}

\author{
Jay Hendrayana ${ }^{{ }^{*}}$ \\ Dewi Kurniati ${ }^{2}$ \\ Novira Kusrini ${ }^{3}$ \\ 1,2,3 Jurusan Sosial Ekonomi Pertanian Fakultas Pertanian Universitas Tanjungpura Pontianak \\ *email: jay.hndra@gmail.com \\ Diterima: Agustus 2020, Disetujui: Oktober 2020, Dipublish: Oktober 2020
}

\begin{abstract}
Abstrak
Kesejahteraan petani adalah tolok ukur utama kesuksesan suatu usahatani. Salah satu usahatani tersebut adalah usaha tani karet khususnya Kabupaten Sanggau. Desa Teraju termasuk sentra produksi karet di Kabupaten Sanggau dan merupakan ibukota Kecamatan Toba. Namun, Karakteristik petani Karet di Kabupaten Sanggau tergolong petani dengan lahan sempit, pendapatan rendah, anggota keluarga banyak, umur petani relatif tua, namun pengalaman juga relatif banyak. Hal tersebut secara teori membuat tingkat kesejahteraan petani menjadi rendah. Tujuan penelitian ini untuk menganalisa hubungan karakterisitik dan kesejahteraan petani di Kabupaten Sanggau dengan mengambil studi kasus di Desa Teraju Kecamatan Toba. Jumlah populasi sebesar 428 petani dengan sampel sebesar 45 petani. Teknik pengambilan data dengan kuesioner dan wawancara. Metode penelitian menggunakan deskriptif kuantiatif dengan teknis analisis korelasi rank spearman. Hasil analisis menggambarkan bahwa umur dan pendidikan memiliki hubungan dengan tingkat kesejahteraan petani.
\end{abstract}

Kata Kunci: Desa Teraju, Karakteristik, Kesejahteraan, Petani Karet, Usahatani Karet

\begin{abstract}
The welfare of farmers is the main measurement to measure agricultural success. One such farm is rubber farming, especially in Sanggau Regency. Teraju Village is a center of rubber production in Sanggau Regency and is the capital of Toba District. However, the characteristics of rubber farmers in Sanggau Regency are classified as farmers with small land, low income, large family members, relatively old farmers, but relatively much experience. This theoretically lowers the welfare of farmers. Therefore, this study aims to determine the relationship between the characteristics of rubber farmers and the welfare of farmers in Sanggau Regency by taking a case study in Teraju Village, Toba District. The population in this study amounted to 428 farmers with a sample of 45 farmers. Data were collected through a research questionnaire and direct interviews. The research method used is descriptive quantitative using Spearman rank correlation analysis. The results showed that only age and education of farmers was related to the farmer's welfare level.
\end{abstract}

Keywords: Characteristics, Farmer Rubber, Welfare, Teraju Village, Rubber Farming

\section{PENDAHULUAN}

Indonesia merupakan negara yang mempunyai keunggulan komparatif berupa sumber daya pertanian yang melimpah. Sebagian besar perekonomian masyarakat Indonesia juga bergantung pada sektor pertanian (Nugraha \& Alamsyah, 2019). Oleh karena itu, pembangunan pertanian menjadi fokus pemerintah dalam upaya meningkatkan kesejahteraan rakyatnya, khususnya petani. Kesejahteraan petani 
tersebut dapat dicapai melalui proses berkelanjutan dengan berusaha meningkatkan pembangunan pertanian (Simatupang, et.al., 2019).

Tanaman karet (Hevea brasiliensis) adalah satu diantara komoditas perkebunan yang penting bagi Indonesia karena menjadi salah satu komoditas ekspor Indonesia untuk devisa negara. Permintaan komoditas ini juga semakin meningkat setiap tahun (Robianto \& Supijatno, 2017). Selain dimiliki oleh perkebunan besar milik Negara atau swasta, karet juga dimiliki oleh rakyat (Wahyuni, et.al., 2013).

Kalimantan Barat adalah salah satu daerah yang menjadikan tanaman karet sebagai komoditas unggulan daerah (BPS, 2019). Tanaman karet menjadi sumber mata pencaharian dan pendapatan utama bagi masyarakat. Pekerjaan sebagai petani tersebut telah dilakukan secara turun temurun. Sentra produksi tanaman Karet terluas di Kalimantan Barat adalah Kabupaten Sanggau (BPS, 2019).

Desa Teraju merupakan ibukota Kecamatan Toba dan mempunyai lokasi yang strategis membuat karet di daerah ini menjadi rujukan daerah lain (BPS, 2020; BPS, Kecamatan Toba dalam Angka 2018, 2018). Selain itu, Luas areal tanaman karet di Desa Teraju juga meningkat setiap tahunnya. Luas areal tanaman karet pada tahun 2015 adalah 6.534 hektar dan menjadi 6.941 hektar pada tahun 2018 (BPS, Kecamatan Toba dalam Angka 2018, 2018; BPS, 2016). Lokasi desa yang merupakan ibukota kecamatan juga membuat produksi karet di desa ini menjadi relatif lebih mudah untuk dijual dan fasilitas infrastruktur yang lebih baik dibandingkan daerah lainnya di Kecamatan Toba.

Namun, harga karet di tingkat petani cukup rendah yaitu seharga $\mathrm{Rp}$ $6.000 \mathrm{per} / \mathrm{kg}$ atau menghasilkan $\mathrm{Rp}$ 6.600.000 per hektar/tahun dengan tingkat produksi 4.000 ton. Selain itu, lahan milik petani juga tergolong sempit (maksimal 1 hektar) dan usia petani yang masuk kategori tua. Kondisi ini mengakibatkan lemahnya posisi daya tawar petani dan akan mempengaruhi posisi kesejahteraan petani lebih rendah di bawah garis kemiskinan. Berdasarkan kondisi tersbut diperlukan adanya upaya perbaikan agar kesejahteraan petani dapat meningkat.

Oleh karena itu, identifikasi faktor faktor dalam karakteristik petani yang berhubungan dengan kesejahteraan petani menjadi penting. Faktor-faktor tersebut akan menjadi faktor pendorong kesejahteraan petani karet pada periode yang akan datang. Konsep terkait karakteristik petani mengacu pada teori yang dikemukakan Suratiyah (2009) bahwa pendapatan juga dipengaruhi oleh faktor internal yang meliputi umur, pengalaman, luas lahan serta pendidikan petani. Selanjutnya teori terkait pengukuran tingkat kesejahteraan mengacu pada ukuran kesejahteraan BPS (2014).

Oleh karena itu, melalui penelitian ini ingin menganalisa hubungan karakteristik dengan tingkat kesejahteraan petani karet di Desa Teraju, Kecamatan Toba, Kabupaten Sanggau. Urgensi Penelitian ini adalah diharapkan dapat mendorong kesejahteraan petani usaha tani karet, 
peningkatan nilai tawar petani, dasar pengambil kebijakan usaha tani karet khususnya di Kabupaten Sanggau, serta menjadi dasar penyuluhan bagi petani yang sesuai dengan masalah yang ada.

\section{METODE PENELITIAN}

Metode penentuan lokasi ditentukan dengan purposive sampling, artinya penentuan lokasi penelitian yang dipilih berdasarkan pertimbangan bahwa daerah tersebut (Sugiyono, 2017) merupakan daerah yang masyarakatnya mengandalkan usaha tani karet di kecamatan Toba dan terletak di pusat pemerintahan Kecamatan Toba yang mempunyai akses terhadap fasilitas masyarakat yang lebih baik, sehingga dianggap mewakili Kecamatan Toba. Penelitian ini dilaksanakan di Desa Teraju, Kecamatan Toba, Kabupaten Sanggau sebagai salah satu sentra produksi karet terluas di Kabupaten Sanggau.

Penelitian ini dilakukan dari tanggal 12 Maret - 12 April 2020. Jumlah populasi sebesar 428 petani dengan sampel penelitian sebesar 45 petani dengan tingkat error 15\% (Sugiyono, 2017). Besarnya sampel ditentukan secara simple random sampling dengan menggunakan rumus Slovin sebagai alat ukur penentuan banyaknya sampel.

Metode penelitian ini dengan metode deskriptif kuantitatif. Jenis data penelitian ini terdiri dari data primer berupa hasil wawancara dan data sekunder berupa studi literatur (Sugiyono, 2017). Analisis data dilakukan dalam dua tahap, yaitu mengukur tingkat kesejahteraan petani menggunakan dasar indikator kesejahteraan rakyat BPS (2014) dan rumus range score dan diklasifikasikan dalam dua kategori yaitu sejahtera dan belum sejahtera. Adapun rumus penentuan range score sebagai berikut:

$\mathrm{RS}=\frac{\mathrm{SkT}-\mathrm{SkR}}{\mathrm{JK} 1}$

Keterangan :

$\mathrm{RS}=$ Range Score

SkT $=$ Skor Tertinggi

SkR $=$ Skor terendah

JK1 = Jumlah Klasifikasi yang digunakan

Selanjutnya dilakukan analisis korelasi untuk mengetahui hubungan antara variabel X (Karakteristik petani karet) menggunakan teori Suratiyah (2009) meliputi umur petani, pengalaman petani Jumlah anggota keluarga, luas lahan serta pendidikan dengan variabel $\mathrm{Y}$ (Tingkat kesejahteraan petani karet) menggunakan BPS meliputi kependudukan, kesehatan dan gizi, pendidikan, ketenagakerjaan, pola konsumsi, perumahan dan lingkungan, sosial dan lain-lain. Perhitungan analisa Spearman Rank dengan rumus sebagai berikut Sugiyono (2017) :

$r s=1-\frac{6 \sum d_{i}^{2}}{n\left(n^{2}-1\right)}$

Keterangan

rs= Nilai korelasi spearman

$d^{2}=$ Perbedaan rangking antara

pasangan data

$\mathrm{n}=$ Banyaknya pasangan data

6 = bilangan konstanta

\section{HASIL DAN PEMBAHASAN}

Karakteristik sosial demografi petani dapat dilihat dari usia, jenis, kelamin, pendidikan petani (Kotler \& Armstrong, 2001).

Gambaran karakteristik petani 
dalam penelitian ini didasarkan pada petani petani karet (tabel 1).

hasil analisa terhadap data dari 45

Tabel 1. Karakteristik Sosial-Demografi Petani Karet

\begin{tabular}{|c|c|c|}
\hline Karakteristik Petani & Jumlah Petani (orang) & Persentase (\%) \\
\hline \multicolumn{3}{|l|}{ Usia Petani (Tahun) } \\
\hline $17-28$ & 3 & 6,6 \\
\hline $29-38$ & 30 & 66,7 \\
\hline $39-58$ & 12 & 26,7 \\
\hline Jumlah & 45 & 100 \\
\hline \multicolumn{3}{|l|}{ Jenis Kelamin } \\
\hline Laki-laki & 38 & 84,4 \\
\hline Perempuan & 7 & 15,6 \\
\hline Jumlah & 45 & 100 \\
\hline \multicolumn{3}{|l|}{ Pendidikan (tahun) } \\
\hline Tidak sekolah & 2 & 4,4 \\
\hline lulus SD & 25 & 55,6 \\
\hline Lulus SMP & 18 & 40 \\
\hline Jumlah & 45 & 100 \\
\hline \multicolumn{3}{|c|}{ Pengalaman Bertani (tahun) } \\
\hline$<10$ & 2 & 4,4 \\
\hline $10-30$ & 11 & 24,4 \\
\hline$\geq 31$ & 33 & 73,3 \\
\hline Jumlah & 45 & 100 \\
\hline \multicolumn{3}{|c|}{ Jumlah Anggota Keluarga (orang) } \\
\hline $1-2$ & 1 & 2,3 \\
\hline $3-4$ & 24 & 53,3 \\
\hline 5- 6 & 20 & 44,4 \\
\hline Jumlah & 45 & 100 \\
\hline \multicolumn{3}{|l|}{ Luas lahan } \\
\hline$\leq 1$ ha & 14 & 31,1 \\
\hline$\leq 2$ ha & 22 & 48,9 \\
\hline$\geq 3$ ha & 9 & 20 \\
\hline Jumlah & 45 & 100 \\
\hline
\end{tabular}

Sumber: Data Olahan (2020)

Responden didominasi laki-laki (85\%) karena laki-laki merupakan tulang punggung keluarga, sedangkan perempuan lebih banyak bekerja mengurus rumah tangga (Mahendra, 2014). Selain itu, umur petani responden didominasi umur usia 29-38 tahun yang termasuk dalam usia produktif, mempunyai kematangan berpikir rasional untuk pengambilan keputusan, produktivitas yang relatif masih baik (Hasyim, 2006; BPS, 2016;
Kurniati \& Jumanto, 2017; Wahyuni, et.al., 2019).

Selanjutnya, tingkat pendidikan petani didominasi tamat SD $(59,2 \%)$ karena kesadaran terhadap pendidikan yang masih rendah. Tingkat pendidikan tersebut akan membuat kemampuan berpikir petani yang akan cenderung terbatas dan cenderung kurang menyukai inovasi baru karena pendidikan berhubungan dengan pola pikir, kemampuan adopsi hal baru, serta 
produktivitas seseorang (Mosher, 2012; Kusumo,et.al., 2017; Cora,et.al., 2018).

Pengalaman bertani petani juga didominasi 31 tahun ke atas $(72,1 \%)$. Pengalaman tersebut relatif lama, sehingga tingkat pengetahuan budidaya sudah sangat baik dan relatif bijak dalam memutuskan sesuatu terkait usahataninya (Kurniati \& Jumanto, 2017; Wahyuni, et.al., 2019).

Jumlah tanggungan keluarga responden didominasi 3-4 orang (53,3\%). Jumlah tanggungan tersebut relatif dapat berpotensi dua hal yaitu membuat beban tambahan bagi keluarga untuk mencari pendapatan tambahan atau meningkatkan kesejahteraan tergantung kondisinya (Purwanto \& Taftazani, 2018).

Luas lahan responden didominasi $\leq$ cenderung lebih mudah dalam penerapan teknologi dibandingkan petani dengan lahan luas karena petani dengan lahan luas cenderung memiliki ketakutan untuk gagal dalam menerapkan teknologi, sehingga menerapkan teknologi yang sudah ada (Pramuditya \& Prihtanti, 2019).

\section{Tingkat Kesejahteraan Rumah Tangga Petani Desa Teraju Kecamatan Toba}

Berdasarkan

BPS

(2014), pengertian kesejahteraan menggambarkan keadaan saat kebutuhan jasmani dan rohani rumah tangga tersebut dapat dipenuhi sesuai dengan taraf hidup. Tingkat kesejahteraan tersebut dikelompokkan menjadi keluarga sejahtera dan keluarga tidak sejahtera.

2 ha. Petani dengan lahan sempit

Tabel 2. Distribusi petani menurut tingkat kesejahteraan

\begin{tabular}{lccc}
\hline \multicolumn{1}{c}{ Kategori } & Jumlah (Orang) & Persen (\%) & Skor \\
\hline Sejahtera & 35 & 77,8 & $15-21$ \\
Tidak Sejahtera & 10 & 22,2 & $7-14$ \\
\hline Jumlah & $\mathbf{4 5}$ & $\mathbf{1 0 0}$ & \\
\hline
\end{tabular}

Sumber: Data Olahan (2020)

Tingkat kesejahteraan Teraju Kecamatan Toba menunjukkan bahwa 77,8 persen petani responden termasuk keluarga sejahtera dan 22,2 persen termasuk keluarga tidak sejahtera (tabel 2). Hal tersebut dapat disebabkan oleh dukungan pemerintah desa dalam bentuk program pembangunan desa untuk meningkatkan kesejahteraan masyarakat sudah sangat baik seperti bantuan sosial. Petani yang kurang sejahtera dapat disebabkan oleh tanggungan keluarga yang relatif banyak, sehingga menambah biaya kebutuhan hidup. Skor rata-rata tiap indikator digambarkan pada Tabel 3 . 
Tabel 3. Rata-rata skor indikator kesejahteraan BPS

\begin{tabular}{lcc}
\multicolumn{1}{c}{ Indikator } & Skor & Keterangan \\
\hline Kependudukan & 3 & Baik \\
Kesehatan dan Gizi & 3 & Baik \\
Pendidikan & 2 & Cukup \\
Ketenagakerjaan & 2 & Cukup \\
Taraf dan Pola Konsumsi & 2 & Cukup \\
Perumahan dan Lingkungan & 3 & Baik \\
Sosial dan lain-lain & 2 & Cukup \\
\hline Total Rata-rata & $\mathbf{1 7}$ & Sejahtera \\
\hline Sumber: Data olahan (2020) & &
\end{tabular}

Tabel 3 menggambarkan bahwa petani termasuk kategori skor cukup dan baik untuk ketujuh indikator kesejahteraan, dengan rata-rata total skor 17. Total skor menunjukkan mayoritas petani termasuk kategori sejahtera. Kondisi ini diakibatkan oleh keadaan Desa Teraju termasuk daerah yang kondisi perekonomiannya cukup strategis karena merupakan ibukota kecamatan. Jumlah responden dalam penelitian ini sebanyak 45 petani. Analisis korelasi rank spearman dengan membandingkan jumlah responden sebesar 45 dengan taraf signifikansi sebesar 5\%. Nilai signifikansinya $<0,05$ berarti terjadi korelasi, serta sebaliknya.

Karakteristik petani yang digunakan dalam analisis ini terdiri atas umur, pengalaman, jumlah anggota keluarga, luas lahan dan pendidikan yang merujuk pada teori Suratiyah (2009).

Tabel 4. Korelasi Karakteristik Petani terhadap Kesejahteraan

\begin{tabular}{lcc}
\multicolumn{1}{c}{ Korelasi } & $\begin{array}{c}\text { Correlation } \\
\text { Coefficient }\end{array}$ & Nilai Signifikansi \\
\hline Umur terhadap kesejahteraan & $-0,163$ & 0,028 \\
Pengalaman terhadap kesejahteraan & $-0,161$ & 0,290 \\
Jumlah anggota keluarga terhadap kesejahteraan & 0,027 & 0,862 \\
Luas lahan terhadap kesejahteraan & $-0,072$ & 0,638 \\
Pendidikan terhadap kesejahteraan & 0,990 & 0,005 \\
\hline
\end{tabular}

Sumber: Data Olahan (2020)

a. Umur

Hubungan kesejahteraan terhadap variabel pertama yaitu Umur. Hasil tersebut menunjukkan nilai koefisien korelasi Spearman umur terhadap kesejahteraan adalah -0,163 yang berarti bahwa tingkat keeratan hubungan yang sangat rendah, nilai koefisien korelasi spearman yang negatif menunjukkan hubungan yang tidak searah atau setiap peningkatan umur petani, kesejahteraan petani akan menurun. Selain itu, tingkat signifikan $0,028<0,05$ memberikan arti bahwa umur dan kesejahteraan mempunyai hubungan yang signifikan antara kedua variabel.

Usia suami ataupun istri termasuk faktor internal yang berkaitan dengan kesejahteraan berdasarkan indikator BPS. Hal tersebut sejalan dengan beberapa teori yang mengemukakan bahwa seseorang akan lebih produktif pada usia yang lebih muda yaitu 15-55 
tahun. Umur kepala keluarga yang lebih tua memiliki kesejahteraan lebih rendah daripada umur kepala keluarga yang lebih muda. Hal ini karena kepala keluarga yang lebih muda dapat lebih produktif dalam bekerja (Asmara, 2017).

b. Pengalaman

Hubungan kesejahteraan terhadap variabel kedua yaitu pengalaman. Hasil tersebut menunjukkan nilai koefisien korelasi Spearman pengalaman terhadap kesejahteraan adalah -0,161 yang berarti bahwa tingkat keeratan hubungan yang sangat rendah, nilai koefisien korelasi spearman yang negatif menunjukkan hubungan yang tidak searah atau semakin lama pengalaman seseorang, semakin tidak sejahtera petani tersebut. Selain itu, tingkat signifikan $0,290>0,05$ menggambarkan pengalaman dan kesejahteraan tidak mempunyai hubungan yang signifikan antara kedua variabel.

Pengalaman petani yang semakin meningkat cenderung akan membuat petani terjebak dalam sistem penjualan hasil produksi karet yang hanya menguntungkan tengkulak (Bakar \& Fauzi, 2013). Sistem produksi karet tradisional tersebut biasanya memberikan harga yang rendah bagi petani dan petani sulit lepas dari hal tersebut karena praktik tersebut sudah berjalan turun temurun. Sementara itu, petani dengan pengalaman sedikit cenderung akan memilih penjualan karet yang lebih menguntungkannya.

c. Jumlah anggota keluarga

Hubungan kesejahteraan terhadap variabel ketiga yaitu jumlah anggota keluarga. Hasil tersebut menunjukkan nilai koefisien korelasi Spearman jumlah anggota keluarga terhadap kesejahteraan adalah 0,027 yang berarti bahwa tingkat keeratan hubungan yang sangat rendah, nilai koefisien korelasi spearman yang positif menunjukkan hubungan yang searah atau setiap peningkatan jumlah anggota keluarga petani, kesejahteraan petani juga akan meningkat. Selain itu, tingkat signifikan 0,862>0,05 menggambarkan jumlah anggota keluarga dan kesejahteraan tidak mempunyai hubungan yang signifikan antara kedua variabel.

Hal tersebut dapat disebabkan oleh kebutuhan pendidikan telah dipenuhi oleh pemerintah melalui sekolah gratis, kebutuhan pangan diusahakan oleh masyarakat sendiri melalui pertanian perkarangan, sehingga jumlah anggota keluarga tidak berdampak terhadap kesejahteraan petani.

d. Luas lahan

Hubungan kesejahteraan terhadap variabel keempat yaitu luas lahan. Hasil tersebut menunjukkan nilai koefisien korelasi Spearman luas lahan terhadap kesejahteraan adalah 0,072 yang berarti bahwa tingkat keeratan hubungan yang rendah, nilai koefisien korelasi spearman yang negatif menunjukkan hubungan yang tidak searah atau setiap peningkatan luas lahan petani, kesejahteraan petani akan menurun. Selain itu, tingkat signifikan $0,638>0,05$

menggambarkan jumlah anggota keluarga dan kesejahteraan tidak mempunyai hubungan yang signifikan antara kedua variabel. Kenyataan di lapangan bahwa luas lahan yang dimiliki 
petani tidak menentukan pendapatan masyarakat, namun lebih dipengaruhi oleh tingkat produktivitas lahan yang digunakan yaitu 1,1 ton/hektar/tahun.

Petani dengan lahan sempit cenderung lebih mudah dalam penerapan teknologi dibandingkan petani dengan lahan luas karena petani dengan lahan luas cenderung memiliki ketakutan untuk gagal dalam menerapkan teknologi, sehingga menerapkan teknologi yang sudah ada (Pramuditya \& Prihtanti, 2019). Penerapan teknologi akan meningkatkan produktivitas lahan, sehingga meningkatkan pendapatan petani.

\section{e. Pendidikan}

Hubungan kesejahteraan terhadap variabel kelima yaitu pendidikan. Hasil menunjukkan nilai koefisien korelasi Spearman antara pendidikan dan kesejahteraan adalah 0,990 yang berarti bahwa tingkat keeratan hubungan yang sangat kuat, nilai koefisien korelasi spearman yang positif menunjukkan hubungan yang searah atau setiap peningkatan pendidikan petani, kesejahteraan petani akan meningkat. Selain itu, tingkat signifikan $0,005<0,05$ menunjukkan pendidikan dan kesejahteraan mempunyai hubungan yang signifikan antara kedua variabel.

Pendidikan termasuk dari segi spiritual dan mental digunakan sebagai dasar mengetahui tingkat kesejahteraan seseorang (Aini, 2018). Faktor pendidikan mempengaruhi pola pikir dan pengambilan keputusan terhadap suatu masalah. Pandangan, pola pikir dan pengambilan keputusan dalam menghadapi suatu masalah dapat ditingkatkan melalui pendidikan
(Moroki, et.al., 2018). Sehingga dengan pendidikan yang semakin tinggi maka memiliki pola pikir yang semakin baik dalam memutuskan sesuatu terkait usahataninya.

\section{SIMPULAN}

Tingkat kesejahteraan petani karet di Desa Teraju tergolong petani sejahtera. Karateristik petani yang berhubungan signifikan dengan kesejahteraan adalah umur dan pendidikan petani. Oleh karena itu, untuk meningkatkan kesejahteraan petani suatu daerah perlu dilakukan regenerasi petani dan pemberian pelatihan kepada petani yang berusia muda untuk dapat meningkatkan kemampuan petani. Bentuk kegiatan yang dapat meningkatkan kemampuan petani muda adalah penyuluhan tentang manajemen usahatani dan inovasi teknologi karet. Petani disarankan untuk dapat mengikuti penyuluhanpenyuluhan untuk membentuk pola dan cara pikir petani karet lebih baik. Peningkatan pengetahuan dan kompetensi tersebut akan mendorong peningkatan produktivitas usahatani. Namun, pemerintah juga mendorong kemudahan input, memberikan informasi bagi petani, menjaga harga pasar karet. Hal tersebut diharapkan dapat meningkatkan kesejahteraan petani melalui peningkatan produktivitas usahatani karet.

\section{DAFTAR PUSTAKA}

Aini, E. N. (2018). Pengaruh Tingkat Pendidikan Terhadap Tingkat Kesejahteraan Masyarakat Di Kelurahan Kesatrian Kota Malang. Technomedia Journal (Tmj), 3(1), 58-72. 
Asmara, N. (2017). Analisis Faktor Faktor Yang Mempengaruhi Kesejahteraan Tenaga Kerja (Studi Kasus Pada Industri Cireng Crispy Shaza Di Bojongsari Depok). Jakarta: Uin Jakarta.

Bakar, B. A., \& Fauzi, E. (2013). Kajian Karakteristik Petani Karet Dalam Menentukan Pilihan Kelembagaan Tataniaga Di Provinsi Aceh. Agrisep, 12(2), 165- 176.

BPS. (2014). Indikator Kesejahteraan Rakyat 2014. Jakarta: Badan Pusat Statistik. Jakarta.

BPS. (2016). Kecamatan Toba Dalam Angka 2016. Sanggau: Bps.

BPS. (2016). Kecamatan Toba Dalam Angka 2016. Sanggau: Bps.

BPS. (2018). Kecamatan Toba Dalam Angka 2018. Sanggau: Bps.

BPS. (2019). Provinsi Kalimantan Barat Dalam Angka 2019. Pontianak: Bps.

BPS. (2020). Kabupaten Sanggau Dalam Angka. Sanggau: Bps.

Cora, G. S., Rukmana, D., \& Amrullah , A. (2018). Persepsi Petani Kakao Terhadap Teknik Sambung Samping Di Desa Batu Lappa, Sulawesi Selatan. Jurnal Sosial Ekonomi Pertanian, 14(1), 15-30.

Hasyim, H. (2006). Analisis Hubungan Petani Kopi Terhadap Pendapatan (Studi Kasus: Desa Dolok Seribu Kabupaten Tapanuli Utara). Jurnal Komunikasi Pertanian, 18 (1), 2227.

Kotler, P., \& Armstrong. (2001). PrinsipPrinsip Pemasaran : Edisi Kedelapan Jilid $1 . \quad$ Jakarta: Erlangga.

Kurniati, S. A., \& Jumanto. (2017). Strategi Pengembangan Usaha Ikan Nila Di Kabupaten Kuantan Singingi Provinsi Riau. Jurnal Agribisnis, 19(1), 13-25.
Kusumo, R. A., Charina, A., \& H, A. (2017). Persepsi Petani Terhadap Teknologi Budidaya Sayuran Organik Di Kabupaten Bandung Barat . Paspalum, 5(2), 19-28.

Mahendra, A. D. (2014). Analisis Pengaruh Pendidikan, Upah, Jenis Kelamin, Usia Dan Pengalaman Kerja Terhadap Produktivitas Tenaga Kerja (Study Di Industri Kecil Tempe Di Kota Semarang). Skripsi.

Mislini. (2006). Analisis Jaringan Komunikasi Pada Kelompok Swadaya Masyarakat. Kasus Ksm Di Desa Taman Sari Kabupaten Bogor Provinsi Jawa Barat. Tesis.

Moroki, S., Masinambow, V. A., \& Kalangi, J. B. (2018). Analisis Faktor-Faktor Yang Mempengaruhi Pendapatan Petani Di Kecamatan Amurang Timur. Jurnal Berkala Ilmiah Efisiensi, 18(05), 132-142.

Mosher, A. T. (2012). Menggerakkan Dan Membangun Pertanian. Jakarta: Rineka Cipta.

Nugraha, I. S., \& Alamsyah, A. (2019). Faktor-Faktor Yang Memengaruhi Tingkat Pendapatan Petani Karet Di Desa Sako Suban, Kecamatan Batang Hari Leko, Sumatera Selatan. Jurnal Ilmu Pertanian Indonesia (Jipi), 24(2), 93-100.

Pramuditya , M. H., \& Prihtanti, T. M. (2019). Persepsi Petani Terhadap Budidaya Gandum Tropis. Agric, 31(2), 177-191.

Purwanto, A., \& Taftazani, B. M. (2018). Pengaruh Jumlah Tanggungan Terhadap Tingkat Kesejahteraan Ekonomi Keluarga Pekerja K3I Universitas Padjadjaran. Jurnal Pekerjaan Sosial, 1(2), 33-43.

Robianto, \& Supijatno. (2017). Sistem Penyadapan Karet (Hevea 
Brasiliensis Muell. Arg.) Di Tulung Gelam Estate, Sumatera Selatan. Buletin Agrohorti, 5(2), 274-282.

Simatupang, R., Satmoko, S., \& Gayatri, S. (2019). Persepsi Petani Terhadap Penggunaan Pupuk Organik Pada Kelompok Tani Tranggulasi, Kecamatan Getasan, Kabupaten Semarang. Jurnal Ilmu-Ilmu Pertanian, 3(1), 59-72.

Sugiyono. (2017). Statistika Untuk Penelitian. Bandung: Alfabeta.

Suratiyah, K. (2009). Ilmu Usahatani. Jakarta: Penebar Swadaya.
Wahyuni, I. N., Sunarsih, \& Prabewi, N. (2019). Persepsi Peternak Terhadap Pemberian Ramuan Herbal Di Kelompok Wanita Tani Dewi Sri Kecamatan Windusari. Jurnal Agrica Ektensia, 13(2), 2027.

Wahyuni, S., Gunawan, I., \& Bahar, E. (2013). Analisis Faktor Produksi Yang Mempengaruhi Pendapatan Petani Karet Di Desa Rambah Hilir Tengah Kecamatan Rambah Hilir Kabupaten Rokan Hulu. Jurnal Sungkai, 1(2), 37-47. 